\title{
Toxicological impact of detergent effluent on juvenile of African Catfish (Clarias gariepinus) (Buchell 1822)
}

\author{
*Ogundiran, M.A., Fawole O.O., Adewoye, S.O. and Ayandiran, T.A \\ Department of Pure and Applied Biology, Ladoke Akintola University of Technology, \\ P. M. B. 4000, Ogbomoso, Nigeria, \\ Email:"kelv2dav@yahoo.co.uk, Tel: +2348034237739 \\ ABSRACTS
}

\begin{abstract}
The toxicity of commercial detergent effluent (containing Linear Alkylbenzene Sulfonates), a household cleaning agent was investigated with emphasis on histopathological effects using Juvenile African mud fish (Clarias gariepinus) with the mean weight $1.7 \pm 0.2 \mathrm{~kg}$ and standard length of $8.3 \pm 0.3 \mathrm{~cm}$. After series of range finding test, the fishes were exposed to lethal concentrations $0.00 \mathrm{mg} / \mathrm{L}, 0.01 \mathrm{mg} / \mathrm{L}, 0.02 \mathrm{mg} / \mathrm{L}, 0.03 \mathrm{mg} / \mathrm{L}, 0.04 \mathrm{mg} / \mathrm{L}$ and $0.05 \mathrm{mg} / \mathrm{L}$ and as well as sub-lethal concentrations $0.000 \mathrm{mg} / \mathrm{L}, 0.002 \mathrm{mg} / \mathrm{L}, 0.003 \mathrm{mg} / \mathrm{L}, 0.004 \mathrm{mg} / \mathrm{L}, 0.005 \mathrm{mg} / \mathrm{L}$ and $0.006 \mathrm{mg} / \mathrm{L}$ of detergent effluent for 56 days in a renewal bioassay procedure. The median lethal concentration $\left(\mathrm{LC}_{50}\right)$ values for lethal and sublethal tests were $0.0166 \mathrm{mg} / \mathrm{L}$ and $0.0038 \mathrm{mg} / \mathrm{L}$ respectively. Respiratory disturbance, erratic swimming, loss of equilibrium, lethargies and sudden fish death were observed in the exposed fish and these varied greatly with differences in concentration of the toxicant and this shows that mortality increases with an increase in concentration. The differences observed in the mortalities of $C$. gariepinus at varying concentrations were significant $(p<0.05)$, an indication that mortality could be a factor of concentration and time of exposure. The liver of the control fish showed normal parenchyma appearance of hepatocyte with normal staining patterns of the cell. In the treated fishes, there was congestion of central vein, vacoulation of hepatocyte, oedema, cellular infiltration and cellular necrosis. Detergent effluent is highly toxic to Clarias gariepinus juveniles, which are more susceptible to this household cleaning agent's effluent; therefore, an indiscriminate discharge of this effluent to the surrounding should be discouraged
\end{abstract}

Keywords: Histopathological, acute toxicity, chronic toxicity, physicochemical and mortality.

\section{INTRODUCTION}

More recently in Nigeria, and other developing nations, pollution of water resources has become a serious problem. Apparently, human and ecological disorder experienced in industrial settlements as a result of improper disposal of chemicals such as detergent effluent calls for careful surveillance on the state of the environment. Only few chemicals have been ecologically tested in Nigeria for safety in spite of their environmental and ecological impact. Recently, the Federal Government of Nigeria is emphasizing the need for adequate environmental protection in any technological and socio-economic development or endeavors by strictly asking industrial operators to sustainably manage the disposal of chemical into natural environment (DPR, 2002).

Detergents are cleaning products derived from synthetic organic chemicals. The cheapness of detergent production from petrochemical sources with its ability to foam when used in acid or hard water gives it an advantage over soaps (Okpokwasili and Nwabuzor, 1988). Surfactants are the components mainly responsible for the cleaning action of detergents. In commercial detergents, the surfactant component is between 10 and 20\%. The other components include bleach, filler, foam stabilizer, builders, perfume, soil-suspending agents, enzymes, dyes, optical brighteners and other materials designed to enhance the cleaning action of the surfactant (Swisher, 1975; Okpokwasili and Nwabuzor, 1988). Generally, detergents are xenobiotic compounds which are usually washed into water bodies and are made up of several compounds of which the active components are the surfaceactive agents or surfactants (Ruiswell et al., 1992). Detergent surfactants are complex organic chemicals where hydrophilic and hydrophobic groups are joined together in the same molecules (Huang et al., 2000). There are various types of surfactants used in detergents formulations; the linear alkylbenzene sulfonate (LAS)-ionic surfactants is the most widely used (McAvoy et al., 1997). It was introduced as biodegradable alternatives to the non-biodegradable branched-chained alkylbenzene sulfonates (Gledhill, 
1974). LAS have been reported by WHO, (1996) to have a high solid adsorption coefficient, which is attributed to the physicochemical properties of the surfactants (Painter and Zebel, 1989). The LAS molecules adsorb to the suspended solid in water bodies and hence end up in sediments along the water course or sludge in treatment plants (Cavalli et al., 2000).

The recommended LAS that was claimed by some researcher to biodegrade perfectly (Gledhill, 1974; WHO, 1996 and McAvoy et al., 1997) have also been reported to poorly degrade in rivers, lakes, ponds and even in soils and this may be toxic to aquatic faunas and floras and can also induce severe damage to vital organs and even haematological, hormonal and enzyme disturbances (Lightowlers, 2004; Ogundiran et al., 2007 and Ogundiran et al., 2009). It has also been discovered that detergent surfactant increases microbial populations especially those that are able to use the surfactant as their basic source of carbon or phosphate or both, some of these microorganisms stands as an ectoparasites or endoparasites that causes histological degradation in fish species (Eniola and Olayemi, 2002, and Adewoye and Lateef, 2004). Detergents are widely used in both industrial and domestic premises to wash equipment, installations, heavy duty machines, vehicles and oil soiled materials. Detergent is a persistent environmental contaminant probably due to its use in the formulation of cleaning agents, pesticides and for dispersing oil spills at seas; so the use, production and exposure, of detergents is unavoidable.

Xenobiotics compounds usually concentrate in the tissues of aquatic biotas and are known to produce cumulative deleterious effects (Abbas, 1998; Abbas and Mahmood, 2003, 2004). Therefore, the application of environmental toxicology studies on non-mammalian vertebrates is rapidly expanding for the evaluation of the effects of noxious compounds (Ayoola a \& b, 2008). Indiscriminate discharge of such compounds that contains mixtures of heavy metals such as herbicide, pesticides, detergent etc, their careless handling, accidental spillage or discharged of treated effluents into natural waterways have harmful effects on the fish population and other forms of aquatic life and may contribute long term effects in the environment (Akhtar, 1986; Olojo et al., 2005 and Ayoola a \& b, 2008). Toxic chemicals cause tissues damage and histophathological degradations as the fish show haematological responses to toxicants; and generally, such degradation of histological origin occurs in the gills, livers, heart, kidney and epidermis of animals. Van
Dyk et al., (2005) reported sublethal levels of metal mixtures of cadmium and zinc to have influence on the histological responses in exposed specimens with the most histological characteristics identified being hyalinization of hepatocyte, increase vacuolation associated with lipids accumulation, congestion of blood vessels and cellular swelling.

Because the liver of fish can be considered a target organ to pollutants, alterations in its structure can be significant in the evaluation of fish health (Myers et al., 1998), and exhibit the effects of a variety of environmental pollutants (Hinton et al., 1992). Moreover, the liver has play a major role in complex enzymatic processes of tetraiodothyronine (thyroxine)-tri-iodothyronine (T4 - T3) conversion. The metabolic rate of hepatocytes is certainly modulated by thyroid hormones. Thyroid dysfunction may perturb liver function, and liver disease affects thyroid hormone metabolism (Malik and Hodgson, 2002). Therefore, clearly more attention has to be paid on the functions of liver when affected by detergent.The liver was examined because it plays primary roles in the metabolism and excretion of xenobiotics compounds with morphological alterations occurring in some toxic conditions (Rocha and Monteiro, 1999). Metals in effluents can either increase or decrease histopathological changes, depending on the additive effects of the reacting metals in such an effluent, concentration, fish species type, physiological status of the fish species, length of exposure and other factors (Paris-Palacious et al., 2000). The monitorization of histological alteration in fish liver is a highly sensitive and accurate way to assess the effects of xenobiotic compounds both in field and in the laboratory.

Contamination of aquatic phase by detergent has been reported in aquatic organisms such as fishes (Adham et al., 2002; Adewoye and Fawole, 2002; Adewoye et al., 2005; Ogundiran et at., 2007 and Ogundiran et al., 2009). These pollutants build up in the food chain and are responsible for the adverse effects and death in aquatic organisms (Farkas et al., 2002). Fishes are widely used to evaluate the health of aquatic ecosystem and physiological changes serves as biomarkers of environmental pollution (Kock et al., 1996). Clarias gariepinus is most widely used because; it is hardy since it is able to tolerate both well and poorly oxygenated waters. It is widely cultivated in Nigeria water bodies, hence used as biological indicators of ecotoxicological studies. Thus, the aim of this study is to investigate the acute and chronic toxicity of detergent effluent on the African cat fish. 


\section{MATERIALS AND METHODS}

Five hundred juveniles of African cat fish (Clarias gariepinus) with the mean weight $1.7 \pm 0.2 \mathrm{~kg}$ and standard length range of $8.3 \pm 0.3 \mathrm{~cm}$, procured from Ladoke Akintola University of Technology, research fish farm, Ogbomoso, Nigeria, were used for this toxicity assay while test solution (i. e. commercial detergent effluent containing Linear Alkylbenzene sulfonates) used in this toxicity test was collected from the discharging point of a detergent industry, Ilorin, Nigeria using composite sampling. The utilization of juveniles was due to the sensitivity nature of juveniles to toxicity tests than the adults (Reish and Oshida, 1987; Solbe, 1995; Odiette, 1999). The test organisms were acclimatized in stock tanks to avoid overcrowding to the laboratory conditions for two weeks and during acclimatization and experimental periods, the test organisms were fed once daily with commercial feed pellets at $5 \%$ crude protein of their body weight, except during acute toxicity test where the organisms were not fed. The remnants containing unconsumed feeds and fecal were removed from the stock tanks and the water was replenished every 24 hours, this is as recommended by (Reish and Oshida, 1987; Oyelese and Fasoranti, 1995 and Odiette, 1999). The water temperature was $30.02 \pm 0.09{ }^{\circ} \mathrm{C}, \mathrm{pH}$ was $8.72 \pm 0.08$ [(The $\mathrm{pH}$ was determined using a $\mathrm{pH}$ meter (model E512), The $\mathrm{pH}$ meter was standardized by buffer of $\mathrm{pH} 7$ and 9 just before use, each time it was engaged in $\mathrm{pH}$ determinations (A.P.H.A, 1985)], total dissolved solids was taken to be $152.0 \mathrm{mg} / \mathrm{L}$, (this was determined to measure the dissolved oxygen consumed by microorganisms using the method of WHO, 1988), , biological oxygen demand was taken to be $1.2 \mathrm{mg} / \mathrm{L}$ using the formula

$$
\begin{aligned}
& \mathrm{BOD}=\mathrm{a}-\mathrm{b} \times 4 \mathrm{ppm} \\
& \text { Where: } \quad a=\text { Titration of distilled water } \\
& b=\text { Titration of water samples } \\
& \text { PPM }=\text { Parts Per Million }
\end{aligned}
$$

And, the dissolved oxygen was $11.02 \pm 1.22 \mathrm{mg} / \mathrm{l}$ (this was taken using the method proposed by $A$. P.H. A.,1985), the formula used was,

$$
\text { Dissolve }\left(x y g e r\left(\mathrm{mgl}^{1}\right)=\frac{\text { (mltitrantN }(8)(1000}{100},\right.
$$

Acute toxicity tests: A static renewal bioassay procedure (ASTM, 1990) was adopted in which the test media was regularly renewed at interval of every 24 hours at the same set concentrations. A preliminary investigation was also carried out to determine the definitive concentrations suitable for the testing chemical as described by Solbe (1995). The definitive concentrations used for the acute toxicity test were $0.01 \mathrm{mg} / \mathrm{L}, 0.02 \mathrm{mg} / \mathrm{L}, 0.03 \mathrm{mg} / \mathrm{L}$, $0.04 \mathrm{mg} / \mathrm{L}$ and $0.05 \mathrm{mg} / \mathrm{L}$ as well as the control $(0.00 \mathrm{mg} / \mathrm{L})$ in two replicates as described by Solbe, (1995) and Rahman et al., (2002). Ten fully acclimatized fish were exposed to each concentration of $80 \times 30 \times 30 \mathrm{~cm}$ tank. The acute test was allowed to stand for 96 hours which permitted us to monitor the behavioral and mortality responses of the test organisms to varying concentrations of detergent effluent, while the $\mathrm{LC}_{50}$ at 96 hours was also determined with probit analysis using SPSS 10 package.

Chronic Toxicity Tests: A static renewal bioassay procedure (ASTM, 1990) was also adopted in which the test media was regularly renewed at intervals of every 24 hours at the same concentrations. Preliminary investigations were also carried out to determine the definitive concentrations suitable for the testing chemical as described by Solbe (1995). Based on this; five (5) different concentrations of the detergent effluent were executed including the control stock all in replicates of two in the order of 0.002 $\mathrm{mg} / \mathrm{L}, 0.003 \mathrm{mg} / \mathrm{L}, 0.004 \mathrm{mg} / \mathrm{L}, 0.005 \mathrm{mg} / \mathrm{L}$ and 0.006 $\mathrm{mg} / \mathrm{L}$. In all the treatments, ten fully acclimatized test organisms were held and the same in the control stock, as described by Rahman et al., (2002) and Solbe (1995). This was to maintain constant concentration of the test media to which test organisms were exposed and to prevent accumulation of toxic metabolites. The sub-acute test was allowed to stand for 56 days which permitted us to monitor the behavioral and mortality responses of the test organisms to varying concentrations of detergent effluent, while the $\mathrm{LC}_{50}$ at 56 days was also determined with probit analysis using SPSS 10 package.

The experiment was allowed to stand for a total period of 56 days while the test medium was also kept aerated with air pumps continuously. The chronic test allowed us to monitor the behavioral, mortality and histopathological responses of the test organisms to varying concentrations of detergent effluent and the $\mathrm{LC}_{50}$ at 56 days was also determined using the probit analysis.

Then, the target organs i.e. liver was removed and prepared for the probable histopathological degradations as described by Luna (1968); Kelly (1979) and Schalm et al., (1975). The organ was decapitated, dissected and assessed individually by separating the experimental fishes from the control fishes. After proper dissection, the livers were carefully removed and small pieces was fixed in 10\% formalin for 24hrs: After which, the livers were 
dehydrated through a series of graded alcohol, cleared in xylene, infiltrated with paraffin in a vacuum oven at $56^{\circ} \mathrm{C}$, then embedded in paraffin wax. Sections of 6 microns thickness were cut, mounted and stained with heamatoxylin and eosin. Each section was then used to make slides of tissue and was observed under microscope (X200) for proper description of their histological structures, appearance, and cell arrangement. The respective photomicrographs of the slides were also taken for proper observation and interpretations of the slides. RESULTS

The physico - chemical analysis of the test reagent (i.e. detergent effluent) was computed in Table 1. The result of the analysis however implicated the effluent to be unsafed and deleterious to aquatic organisms when compared with Federal Environmental Protection Agency FEPA, (1991) specification and safe limit for effluent discharge into any categories of water bodies.

Table 1. Chemical Analysis of test regent

\begin{tabular}{lcc}
\hline \multicolumn{1}{c}{ Parameters } & $\begin{array}{c}\text { Detergent Industry } \\
\left(\mathbf{m g 1}^{-\mathbf{1}}\right)\end{array}$ & $\begin{array}{c}\text { FEPA 1991 } \\
\left.\text { Specifications } \mathbf{( m g 1}^{-\mathbf{1}}\right)\end{array}$ \\
\hline $\mathrm{pH}$ & 8.7 & $6-9$ \\
Dissolved Oxygen & 3.0 & 5.0 \\
Total suspended solids. $\left(\mathrm{mg1}^{-1}\right)$ & 198.0 & 30 \\
Oil and grease & 22.0 & 10.0 \\
Alkalinity & 55.0 & 45.0 \\
Biological Oxygen Demand & 57.5 & 50 \\
Manganese & 0.25 & 100 \\
Nitrate & 8.5 & 20 \\
Cadmium & 0.06 & $<1.0$ \\
Lead & 0.015 & $<1.0$ \\
Zinc $\left(\mathrm{mg1}^{-1}\right)$ & 1.20 & $<1.0$ \\
Copper & 0.14 & $<1.0$
\end{tabular}

Toxicity of Detergent Effluent: The The $\mathrm{LC}_{50}$ value based on probit analysis was however found to be $0.018 \mathrm{mg} / \mathrm{L}$ for acute 96 hours test and $0.0038 \mathrm{mg} / \mathrm{L}$ for chronic toxicity test and is as presented in figures 1 and 2 respectively. This showed the linear relationship between the probit mortality and the log lethal and sublethal concentrations of detergent effluent. this revealed a positive correlations and also revealed a significant variations at $p<0.05$ which can simply be interpreted that the mortality rates of the exposed fishes at the two tests increases as the concentration of the effluent increased (Table 2 and 4). At the control fishes no adverse behavioral responses or any record of mortality was recorded throughout the period of the bioassays, however, normal behavior and color was noticed all through the toxicity tests. But the detergent exposed fishes showed some signs of stress, lack of balance, erratic movement, gasping for breath, over secretion of mucus, loss of equilibrium and those that cannot tolerate the changing environment gradually becomes weak and settled at the bottom tank and later died with shining appearance of the skin color.

Histopathological investigations of the liver: Table 6 shows the summary of probable liver tissue alterations that were observed in the test organisms exposed to varying chronic concentrations of detergent effluent for 56 days. The photomicrographs of the excised liver were presented in plates of groups 1 to 3 .

In the control experiment, the photomicrograph of the liver showed the typical network of parenchymatous appearance forming an irregular clump made up of hepatocytes $(H)$ and the sinusoids were properly arranged (SD). The interspaces are the sinusoids (S) which are characteristics of a thin sparse connective tissue and are regularly converge into the large central vein $(\mathrm{V})$. The sinusoids make continuous communication as they are seen converging into the central vein (V) (Plate 1a) Mg. (X200).

Plate $1 b$ showed little or no alteration, only that the central vein is prominently shown with centrally located nucleus $(\mathrm{N})$ with little sinusoidal distortion (SD). (Plate 1b) Mg. (X200). The hepatic tissue of the remaining detergent exposed liver (Plates $2 a \& b$ and $3 a \& b$ ) revealed varied degree of cirrhosis (which is an indication of a chronic but progressive diseased condition of the liver characterized by the replacement of healthy cells of tissue with scar tissues) which was evident in the density of fibrous 
connective tissue within and around the hepatic tissue, congestion (which is an indication of congest density of connective tissues) at the sinusoids and central vein with an appearance of focal area of haemorrhage occupying the central vein. The degree of the congestion was varied with concentration and usually located at the region of hepatic tissues and bile ducts; necrosis was minimal but concentration dependent. The degree of cirrhosis, congestion and necrosis was however noted to be concentration dependent. Also noticed was cellular infiltration of hepatocyte $(\mathrm{CH})$ (Plates $2 \mathrm{a} \& \mathrm{~b}$ and $3 a \& b) \mathrm{Mg}$. (X200). At a prolonged period of exposure and under high concentrations (i.e. $0.005 \mathrm{mg} / \mathrm{L}$ and $0.006 \mathrm{mg} / \mathrm{L}$ ) extensive congestion, necrosis of the liver tissue was noticed particularly necrosis of the focal area of parenchyma cells which is a common feature in catfish; cellular infiltration of hepatocyte $(\mathrm{IH})$ was more pronounced at increased concentrations. (Plates 3a\& b ) (Mg. x200)
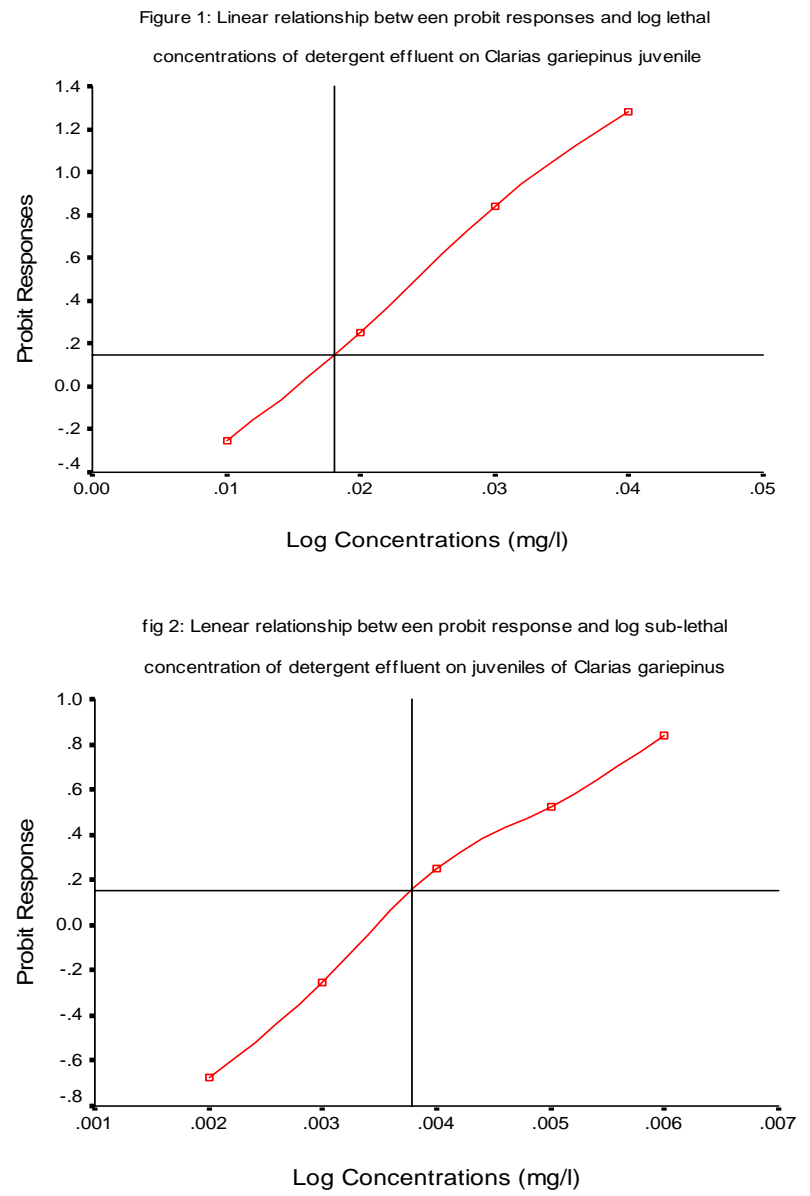

\section{DISCUSSION}

Detergents, including the biodegradable ones have been discovered to induces poisonous effects and osmoregulatory imbalances in aquatic lives especially if present in concentration that exceed metabolic demand; such xenobiotic compounds could be persistence and more mobile in soil and water, hence, it is known to be one of the most common terrestrial and aquatic contaminants (Cox 1998). The detergent effluents are also noticed to induce severe damage to such vital organs like the gills, kidney, liver, skin, heart and the brain.

This present research showed a number of deviations from FEPA (1991) specification for maximum limit allowed for effluent discharge into water bodies in terms of the physicochemical parameters of the effluent in question. The concentrations of lead, copper and manganese in the effluent fell within FEPA (1991) specification, but that is not to say that, their residual effects which may impair organs like the gills, liver, brain, kidney and genital organs should be ruled out. Low dissolved oxygen (DO), high biochemical oxygen demand (BOD), high total suspended solid (TSS) and high alkalinity were also recorded which could be attributed to the high level of organic load in the wastewater thus give room for biodegradative activities of anaerobic bacteria whose end product is foul smell. Warren (1977); Adewoye and Fawole (2002) and Adewoye et al., (2005) had earlier reported that indiscriminate deposition of effluent into an aquatic system might decrease the dissolved oxygen concentration, which stand to impair respiration leading to asphyxiation (which is an indication of unconsciousness or death produced by failure of the blood to become properly oxygenated in the lungs) and may ultimately results into organ architectural degradation such as liver dysfunction. Copper, cadmium lead and zinc that fell within or below tolerable limit could also by way of their additive effect become toxic to all forms of aquatic lives and this result conform with the submission of Adewoye et al., (2005) which opined that if concentration of metals fell within or below FEPA (1991) specifications, it could also be biomagnified in the water, the resultant effect could be gradual accumulation of the metals in water which in turn become toxic to aquatic organisms. 
Agric. Biol. J. N. Am., 2010, 1(3): 330-342

Table 2: Rate of Mortality Of Clarias gariepinus juvenile on Exposure to Varying Lethal concentrations of Detergent Effluent

\begin{tabular}{|c|c|c|c|c|c|c|c|c|c|c|c|c|c|c|c|c|c|c|c|c|c|c|}
\hline $\begin{array}{l}\text { Concentrations } \\
\text { /Hours }\end{array}$ & 1 & 5 & 10 & 15 & 20 & 25 & 30 & 35 & 40 & 45 & 50 & 55 & 60 & 65 & 70 & 75 & 80 & 85 & 90 & 96 & $\begin{array}{l}\text { Total } \\
\text { Mortality }\end{array}$ & $\begin{array}{c}\% \\
\text { Mortality }\end{array}$ \\
\hline $\begin{array}{ll}\text { Conc. } & 0.00 \mathrm{~A} \\
\text { Conc. } & 0.00 \mathrm{~B}\end{array}$ & & & & & & & & & & & & & & & & & & & & & $\begin{array}{l}00 \\
00\end{array}$ & $\begin{array}{l}00 \\
00\end{array}$ \\
\hline $\begin{array}{ll}\text { Conc. } & 0.01 A \\
\text { Conc. } & 0.01 B\end{array}$ & & & & & & & & & & & & & & & & & 01 & 01 & $\begin{array}{l}01 \\
01\end{array}$ & $\begin{array}{l}02 \\
02\end{array}$ & $\begin{array}{l}3 \\
5\end{array}$ & $\begin{array}{l}30 \\
50\end{array}$ \\
\hline $\begin{array}{ll}\text { Conc. } & 0.02 A \\
\text { Conc. } & 0.02 B\end{array}$ & & & & & & & & & & & & 01 & 01 & & $\begin{array}{l}01 \\
01\end{array}$ & 01 & & $\begin{array}{l}01 \\
01\end{array}$ & $\begin{array}{l}01 \\
01\end{array}$ & $\begin{array}{l}01 \\
02\end{array}$ & $\begin{array}{l}4 \\
8\end{array}$ & $\begin{array}{l}40 \\
80\end{array}$ \\
\hline $\begin{array}{ll}\text { Conc. } & 0.03 A \\
\text { Conc. } & 0.03 B\end{array}$ & & & & & & 01 & 01 & 02 & & $\begin{array}{l}01 \\
01\end{array}$ & 01 & 01 & 01 & & 01 & 01 & 01 & 01 & 01 & $\begin{array}{l}01 \\
01\end{array}$ & $\begin{array}{l}9 \\
7\end{array}$ & $\begin{array}{l}90 \\
70\end{array}$ \\
\hline $\begin{array}{ll}\text { Conc. } & 0.04 A \\
\text { Conc. } & 0.04 B\end{array}$ & & & $\begin{array}{l}01 \\
01\end{array}$ & $\begin{array}{l}01 \\
01\end{array}$ & 01 & 01 & 01 & & 01 & 01 & 01 & & & 01 & 01 & 01 & 01 & 01 & 01 & 02 & $\begin{array}{c}8 \\
10\end{array}$ & $\begin{array}{c}80 \\
100\end{array}$ \\
\hline $\begin{array}{ll}\text { Conc. } & 0.05 A \\
\text { Conc. } & 0.05 B\end{array}$ & & & $\begin{array}{l}01 \\
01\end{array}$ & $\begin{array}{l}01 \\
01\end{array}$ & $\begin{array}{l}01 \\
01\end{array}$ & & 01 & & $\begin{array}{l}01 \\
01\end{array}$ & & 01 & 01 & & $\begin{array}{l}01 \\
01\end{array}$ & & & 01 & 01 & 02 & $\begin{array}{l}02 \\
02\end{array}$ & $\begin{array}{l}10 \\
10\end{array}$ & $\begin{array}{l}100 \\
100\end{array}$ \\
\hline
\end{tabular}

NOTE: $A=1^{\text {st }}$ replicate.

$B=2^{\text {nd }}$ replicate. 
Agric. Biol. J. N. Am., 2010, 1(3): 330-342

Table 3: Rate of Mortality of Clarias gariepinus juvenile on Exposure to Varying Sub-lethal Concentrations of Detergent Effluent

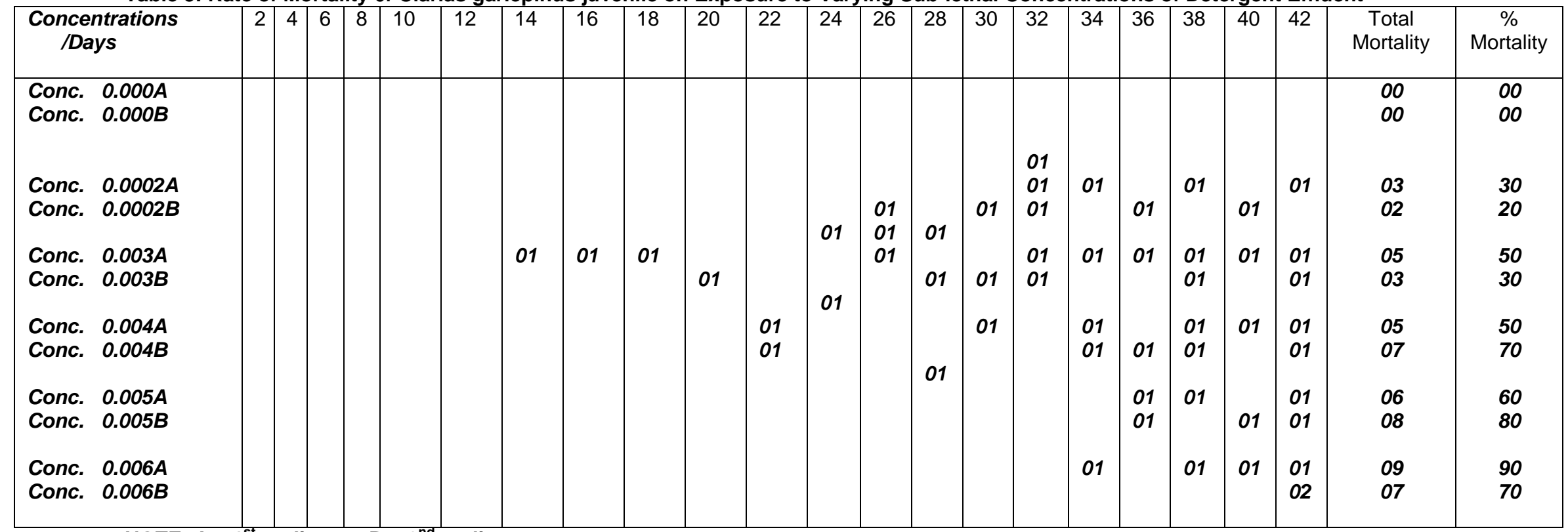

NOTE: $A=1^{\text {st }}$ replicate. $B=2^{\text {nd }}$ replicate.

Table 4: Summary of histopathological changes observed in the liver of Clarias gariepinus subjected to varying sub-lethal concentrations of detergent effluent for 65 days.

\begin{tabular}{|c|c|c|c|c|c|c|}
\hline Detergent Concentration & Period of Exposure & Organ & Oedema & $\begin{array}{l}\text { Congestion } \\
\text { \&vaculation }\end{array}$ & $\begin{array}{l}\text { Cellular infilteration } \\
\text { and Hypertrophy }\end{array}$ & Necrosis \\
\hline Control $\left(0.000 \mathrm{mgl}^{-1}\right)$ & 56 days & Liver & - & - & - & - \\
\hline$\left(0.002 \mathrm{mgl}^{-1}\right)$ & 56 days & Live & - & - & - & - \\
\hline $0.003 \mathrm{mgl}^{-1}$ & 56 days & Liver & - & + & $1 / 2$ & $1 / 2$ \\
\hline $0.004 \mathrm{mgl}^{-1}$ & 56 days & Liver & $1 / 2$ & $1 / 2$ & ++ & $1 / 2$ \\
\hline $0.005 \mathrm{mgl}^{-1}$ & 56 days & Liver & + & ++ & ++ & ++ \\
\hline $0.006 \mathrm{mgl}^{-1}$ & 56 days & Liver & ++ & +++ & +++ & +++ \\
\hline
\end{tabular}

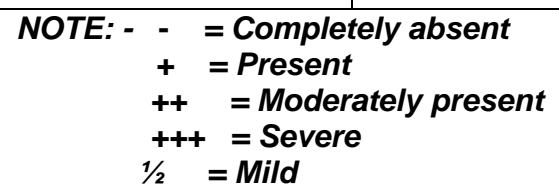


The acute $96 \mathrm{~h} \mathrm{LC}_{50}$ value of the detergent effluent was $0.018 \mathrm{mg} / \mathrm{L}$ while that of the chronic toxicity test was found to be $0.0038 \mathrm{mg} / \mathrm{L}$. These values fell within the concentrations ranges reported in the previous studies of Ikpi et al., (2003) Adewoye et al., (2005) for $O$. niloticus and C. gariepinus respectively. They however observed that at such concentrations the behavioral activities of the organisms would be disrupted and the fitness of the natural population size of an aquatic environment become relatively impaired. Detergent toxicity is however noted to be

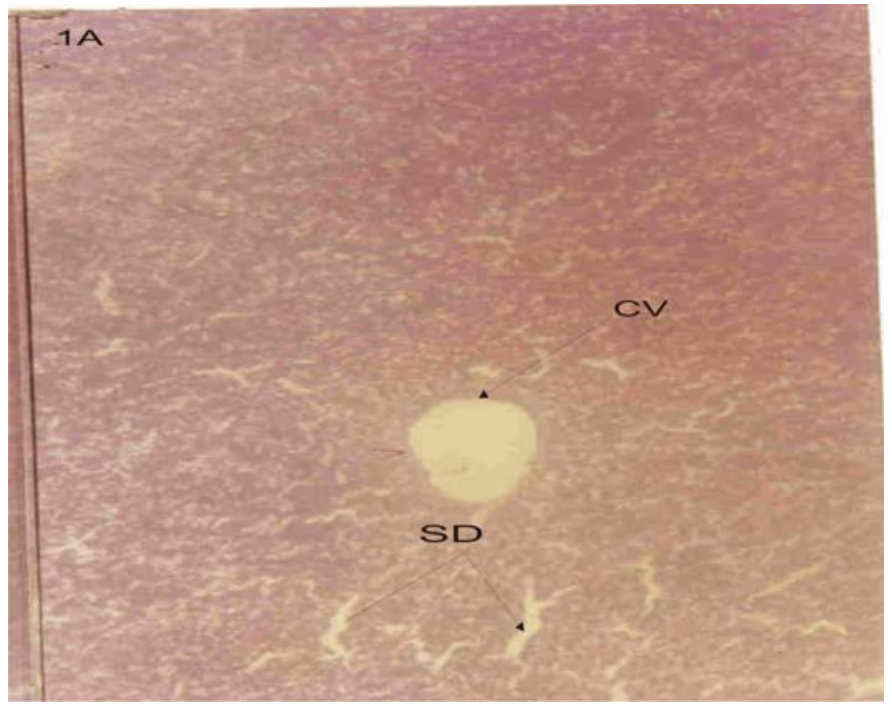

Figure 1a: At control experiment $\left(0.000 \mathrm{mgl}^{-1}\right)$, Liver tissue showed normal lattice network of parenchymatous cells. Central vein (CV), prominently shown without a central nucleus. Partial sinusoidal distortion (SD) without any evidence of cell lyses. (X200 mg)

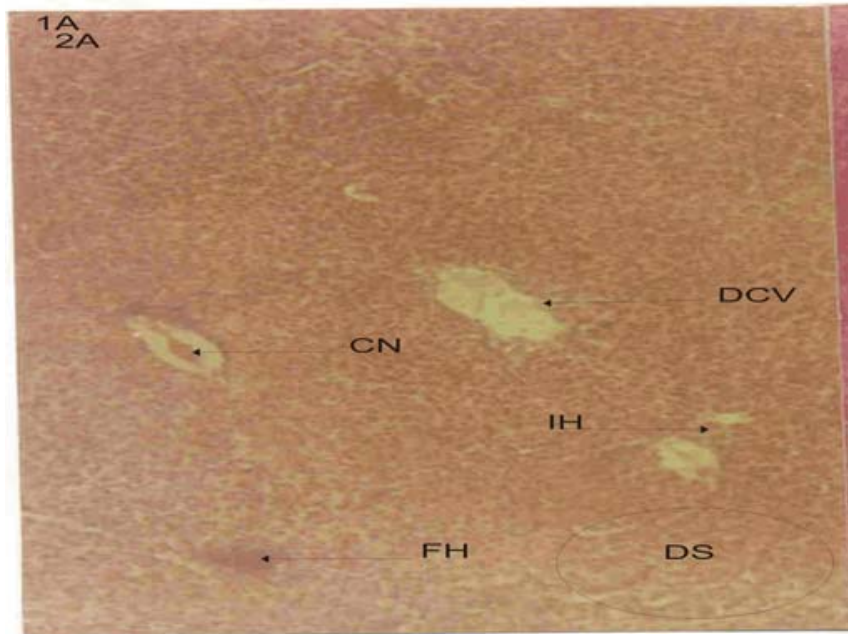

Figure 2a: At $0.003 \mathrm{mgl}^{-1}$, slight degeneration of central vein (DCV) became evident with mild congestion of nuclei (CN). The sinusoidal network loosed their normal arrangement and appearance with partial degeneration increased with increased concentration. Linear relationship between the probit mortality and the log concentrations of detergent effluent indicating a positive correlation and showed a significant difference at $p<0.005$ indicating a high mortality rate of the exposed fish at the increased as the concentrations of the detergent effluent. Ayoola a and b, (2008) reported that the level of toxicity of any toxicant depends on its bioaccumulation, the chemistry of the compound and the reactions of the organisms to the toxicant.

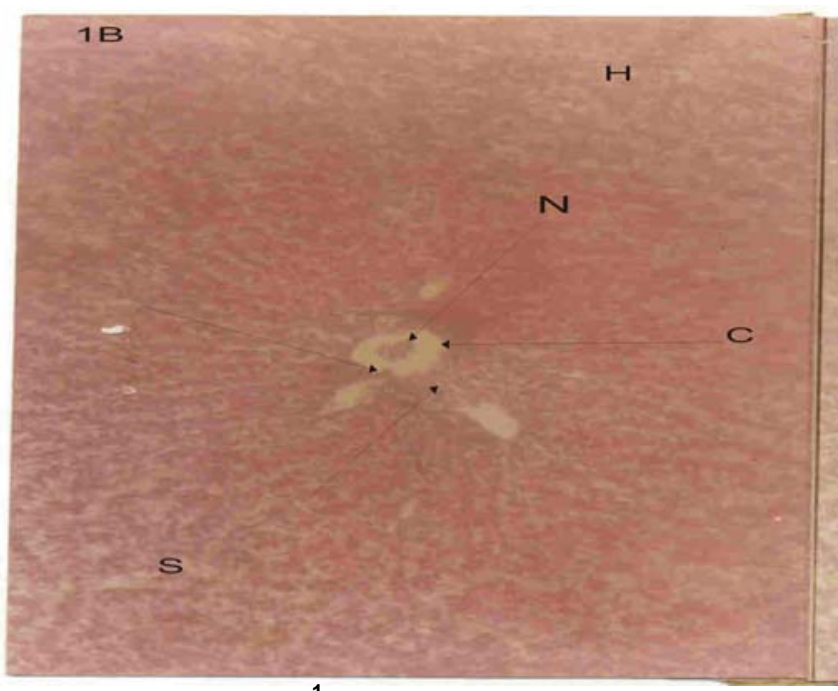

Figure 1b: At $0.002 \mathrm{mgl}^{-1}$, lattice network of parenchymatous cells which was also noticed with formation of an Irregular clumps. Convergence of sinusoids (S) into the large central vein (Arrow direction). Partial distrupted hepatocyte (H).(X200 mg)

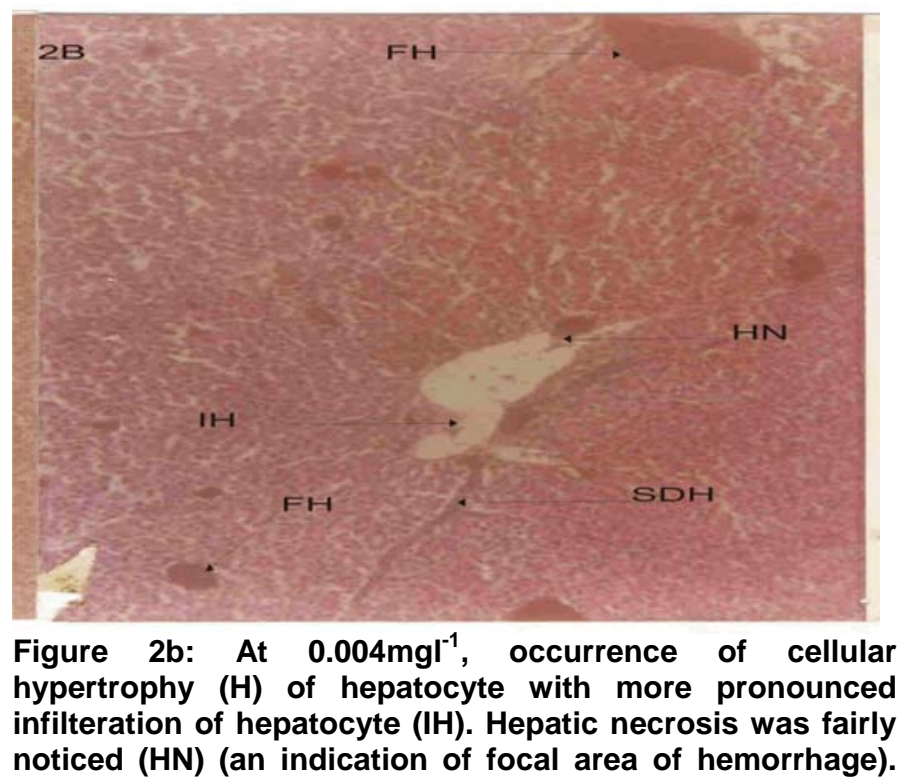


(SD). Infilteration of hepatocytes (IH) with focal area of hemorrhage (FH). (X200 mg).

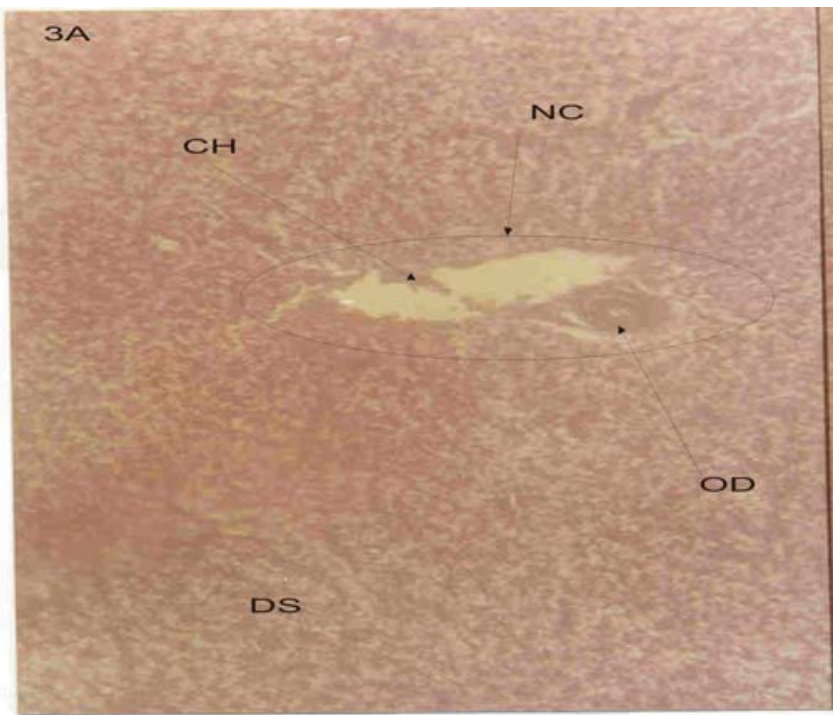

Figure 3a: At $0.005 \mathrm{mgl}^{-1}$, Cellular hypertrophy $(\mathrm{CH})$ with a pronounced Infilteration of hepatocyte, Necrotic cells (NC) coupled with a severe congestion of central vein (an oedematous cell (OC)), all became more pronounced. (X200 mg.).

Behavioral abnormalities have been attributed to nervous impairment as a result of blockage of nervous transmission between the nervous systems and various effectors sites, enzyme dysfunctions that may induce paralysis of respiratory muscles and/or depression of respiratory centre and disturbances in energy or metabolic pathways which results in depletion of energy. No adverse behavioral changes or any mortality were recorded in the control experiment throughout the period of the bioassay. While in the effluent treated fishes, several abnormal behavioral response were observed and recorded such as incessant jumping and gulping of air, restlessness, frequent surface to bottom movement, sudden change of direction during movement, resting at the bottom, loss of skin coloration, loss of equilibrium and gradual onset of inactivity. The observation was similar to the observation of Omoregie et al., (1990); Okwuosa and Omoregie, (1995); Avoajah and Oti (1997); Syed (2001); Omoniyi et al., (2002); Rahman et al., (2002) and Aguiwo (2002). The small changes observed in the lower lethal and sublethal concentrations of the detergent effluent $(0.01 \mathrm{mg} / \mathrm{L}, 0.02 \mathrm{mg} / \mathrm{L} \& 0.03 \mathrm{mg} / \mathrm{L}$ and $\quad 0.002 \mathrm{mg} / \mathrm{L}, \quad 0.003 \mathrm{mg} / \mathrm{L} \quad \& \quad 0.004 \mathrm{mg} / \mathrm{L}$ respectively), may be due to the avoidance behavior of the test organisms to the detergent effluent, this conformed with the submission of (Donalson and
(X200 mg)

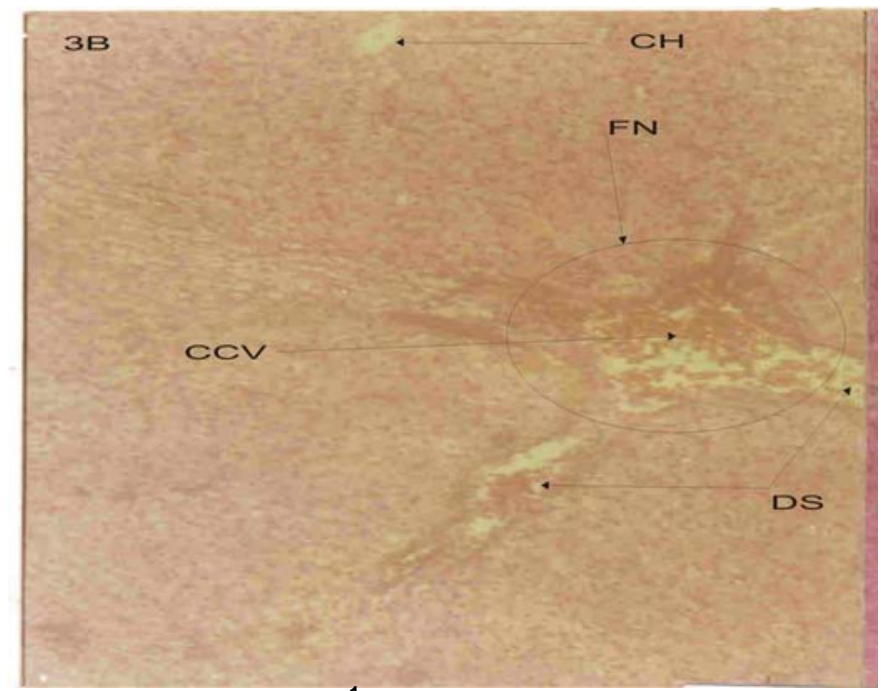

Figure 3a: At $0.006 \mathrm{mgl}^{-1}$, severe focal necrosis (FN), congestion of the central vein (CCV), cellular hypertrophy (CH) and an elaborate sinusoidal distortion (SD) with congestion of sinusoidal lumen, all these anomalies are indication of cirrhosis.

Dye,1975) who are of the opinion that, fish exposed to low concentration of toxicant do not reach the stage of exhaustion, rather they quickly become adapted to the stressor. The stressful and erratic behavior of the fish in this investigation gives a signal to respiratory impairment, and this may be as a results of the effect of the detergent effluent on the gills, this is in agreement with the opinion of Adewoye, et al.,(2005); Ayoola, (2008) and Ogundiran, et al., (2009). At increased lethal and sublethal concentrations $(0.04 \mathrm{mg} / \mathrm{L} \& 0.05 \mathrm{mg} / \mathrm{L}$ and $0.005 \mathrm{mg} / \mathrm{L} \& 0.006 \mathrm{mg} / \mathrm{L}$ respectively), the behavioral responses of the test organisms greatly increased and the organisms later inactive and this is a normal situation in acute and sub-acute toxicity test (Kulakkattolickal and Kramer, 1997). Hyperactivities observed in this study are attributed probably due to the disturbances in the metabolic state resulting in the depletion of energy. It is possible that animals which have higher metabolic activities could require higher level of oxygen and thus would embark on higher respiratory activities (Canli and Kargin, 1995). Lethargies and loss of equilibrium observed in this study may be due to depletion of energy in the body of the exposed animals. Also, Lethargies and loss of equilibrium as recorded in this work is an indication of impairment abnormal carbohydrate metabolism and are possible results of hormonal impairment 
(Anderson et al., 1988). This study revealed the impairment of the carbohydrate metabolism, which resulted in the depletion of energy, causing Lethargies and loss of equilibrium and those organisms that cannot tolerate the toxicant enter into a state of coma and later died. It was also observed that, the rate of mortality became greatly increased with increased in the concentration of the detergent effluent. This is the reflection of what Fryer (1977) reported as regards all categories of toxicant; a threshold is reached at which there is no drastic survival of animal. Animal lies within a tolerable zone only below the threshold, but above the tolerance zone are the zone of resistance.

Histological investigation of the liver tissues (Table 6) showed a typical structural organization of the parenchymatous cell appearance of the hepatocytes in the untreated fishes (Plate 1a). However in this present study, the fishes in the treated (Plate $\mathrm{s} 1 \mathrm{~b}, 2 \mathrm{a}$ $\& b$ and $3 a, b)$, the major histological abnormalities observed were oedema, cellular infiltration, congestion of central vein and cellular necrosis, which showed a progressive architectural distortion at varied concentrations and period of exposures; this is in agreement with the submission of Strivastava and Strivastava (1994) who reported that teleost accumulated lead $(\mathrm{Pb})$ both directly from diet and indirectly from the aqueous medium through an active food chain by the surface lamellae. The most generally encountered type of degenerative changes was congestion, vacuolization of hepatocyte, cellular infiltration and focal necrosis. The liver of the exposed organisms revealed slight vacuolated cells which is an indication of fatty degeneration of hepatocytes. Cellular necrosis as observed in this work probably resulted from excessive work required by the fish to get rid of the toxicants from its body during the process of detoxification. High accumulation of several components of the detergent effluent in the liver is a pointer to the fact that, liver plays a major role in the accumulation and detoxification. Frieberg et al., (1971) submitted that, fishes are known to possess sequestering agent (metallothionein), the bioaccumulation of these trace elements in the liver tissue reaches a proportion in which the function of the liver is impeded, thus resulting in a progressive degeneration of the liver cells synctial arrangement.

Therefore, necrosis became evident as the concentration increases and this may be due to the inability of fishes to regenerate new liver cells. It was also observed that the histopathological changes in the liver caused metabolic problems; this is evident and more pronounced as observed in the oedematous cells (which is an indication bile stagnation in the liver of exposed fish); this lesion is characterized by the remains of the bile in the form of droplets in the cytoplasm of the hepatocyte and this convincingly supported the submission of Pacheco and Santos, (2002) that stated that bile is not being released from the liver - which is also an indication of possible damage to the hepatic metabolic functions of the liver. An increased in the degree of damages done to the liver tissue of the fishes (Clarias gariepinus) held in $0.004 \mathrm{mg} / \mathrm{L}, 0.005 \mathrm{mg} / \mathrm{L}$ and $0.006 \mathrm{mg} / \mathrm{L}$ detergent effluents, is generally related to important hepatic lesions such as degenerative and necrotic processes, this observation was in line with the submission of Chang et al., (1998) and Pacheco and Santos (2002). Furthermore, the presence of bile stagnation/accumulation and melanomacarophages in great quantity in the liver of exposed $C$. gariepinus is strong evidence that this organ suffered structural and metabolic damage due to the exposure to the effluent. This is in a way signaling the fact that this environment where the effluent is discharged is grossly polluted and impaired (Haaparata et al., 1996).

The histological alterations identified within the hepatocytes in this study may have been the results of various biochemical lesions. Anomalies such as irregular shaped central vein, cellular vacuolation and infiltration may be attributed to the accumulation of lipids and glycogen due to liver dysfunction as a results of exposure to the toxicants, this is in conformity with the submission of Fanta et al., (2003) who worked with Siluriform Corydoras paleatus contaminated by organophosphate pesticides, which are related to the normal metabolic function of the liver. Pacheco and Santo (2003) also described increased level of vacuolation of the hepatocytes as a signal to the degenerating process that suggest metabolic damage, possibly related to exposure to contaminated water. The liver parenchyma cells of all exposed specimens showed signs of degeneration stated earlier except the focal necrosis (which is an advance stage of hepatic or fatty degeneration) that was observed as the concentration of detergent effluent increased; here the gross liver alterations were more severe and this has been associated with the exposure of fishes to contaminant of such magnitude such as the mixtures of copper and zinc as reported for poly chlorinated biphenyls (PCBs) Chang et al., (1998), mercury Oliveira, et al., (1996) and Paris-Palacios et al., (2000). 
Therefore, the histological changes observed in the liver of the $C$. gariepinus in the present study indicate that the fish were responding to the direct and the additive effects of the contaminants as much as other effects such as stress. Such information confirms that histopathological alterations are good biomarkers for both field and laboratory assessment, particularly in tropical areas that are naturally subjected to a multiplicity of environmental variations or depletion due to chemical contamination.

Conclusively, this study has been able to establish the fact that, exposure of $C$. gariepinus juvenile to even low concentrations $(0.003 \mathrm{mg} / \mathrm{L})$ of detergent effluent can induce various toxicological effects and histological degradation, which dependent on the period of exposure and concentration of toxicant. In view of the toxicity effect of this effluent, it can be inferred that, indiscriminate discharge of detergent effluents can induce damages to the tissue and organ, which might make all the living entities in polluted environment vulnerable to diseases, and eventually leads to death. Therefore, there is need for the adoption of proper effluent treatment technology which would ensure proper treatment of industrial effluents prior to their discharge into the environment. Although, in a developing country like the Nation Nigeria, several numbers of legislations exist on the quality assurances of water resources but such legislations are rarely followed and yet Industrial growth and its associated environmental problems such as water and sediment contamination are fast increasing. So there is the need for us to imbibe from such developed nations where environmental monitoring agencies are more effective and environmental laws and legislations are strictly followed. General environmental quality monitoring is compulsory and the monitoring of the quality of water resources is done on a regular basis and as a result, any abnormal changes in the water quality can easily be detected and appropriate action is taken before the outbreak of epidemics.

Also, more work is needed to be done on the genotoxic and the cytotoxic effects of this effluent, as this will allow us to draw certain conclusions on the impacts of detergent effluents in our environment.

\section{REFERENCES}

Abbas, H. H. H., (1998): Toxicological effect of copper and lead on some physiological aspects in two fish species, blue tilapia. Oreochromis niloticus ans African catfish, Clarias gariepinus.Ph.D Thesis, Faculty of Science, Cairo University, Egypt
Abbas, H. H. H., and Mahmood, H. M. (2003): The toxicological effect of water pollution on the Nile Tilapia fish (Oreochromis niloticus) collected from four sites along the River Nile. J. Egypt Vet. Med. Assoc. 63: 307-323.

Abbas, H. H. H. and Mahmood, H. M. (2004): Haematological and biochemical changes in Oreochromis aureus and Clarias gariepinus exposed to mixtures of copper and lead salts. Egypt J. Basic. Appl. Physiol., 3: 89-106.

Adewoye, S. O. and Fawole, O. O. (2002). Acute toxicity of soap and detergent effluent to fresh water Clarias gariepinus fingerlins. African J Sci (In press).

Adewoye, and Lateef, A. (2004): Evaluation of the microbiological characteristics of Oyun river - A polluted river in North-central Nigeria. Pollution Res 23(14); 587 - 591.

Adewoye, S.O., Fawole, O.O., Owolabi, O.D. and Omotosho, J.S. (2005).Toxicity of cassava wastewater effluents to African catfish: Clarias gariepinus Ethiop. J. Sci., 28 (7): 189-194.

Adham, K. G., Hamed, S. S. Ibrahim, H. M. and Saleh, R. A. (2002): Impaired functions of Nile Tilapia, Oreochromis niloticus from polluted waters. Acta Hydrochemical et Hydrobiological

Aguiwo, J. N. (2002): The toxic effects of cymbush pesticides on growth and suevival of African catfish, Clarias gariepinus (Bchell, 1822). J. aquat. Sci. 17(2): 81-84.

Akhtar, M. H. (1986): the deposition of ${ }^{14} \mathrm{C}$ agrochemical residues in plants and animal tissues when consumed by animals. In: Green halgh, T. and Roberts, T. R., (eds). Pesticide science and biotechnology. Proceedings of the $6^{\text {th }}$ international congress of pesticides chemistry Ottawa, Canada, August 1986, pp. 10-15

Anderson, T.,Forlin, L., Hardig, J. and Larsson, A. (1988): Physilogical disturbances in fish living in coastal water polluted with bleached kraft pulp mill effluents. Can. J. Fish. Aquat. Sci. 45: 1525-1536.

APHA (1985): Standard methods for the examinatin of water and wastewater. American Public Health Association $16^{\text {th }}$ edition, Washington DC. pp 1268

ASTM(American Society for Testing of Materials) methods 729- 90: (1990). Guide for conducting acute toxicity test with fishes, macro invertebrates and amphibians.

Ayoola, S. O. (2008a). histopathological Effects of Glyphosate on juvenile African Catfish (Clarias gariepinus) Ameri-surasian J Agric \& Environ Sci. 4 (3) 362-367. 
Ayoola, S. O. (2008b). Toxicity of Glyphosate herbicides on Nile tilapia (Oreochromis niloticus) juvenile. Afric. J. Agric. Res. 3 (12) 825- 834.

Avoajah, D.A and Oti, E.E (1997): Effect of sublethal concentration of some pesticides on the growth and survival of the fingerlings of the African Freshwater Catfish: - Heteroclarias (Hybrid fingerlings) Nigeria $\mathrm{J}$ Biotechnol 8; $40-45$.

Canli, M. and Kargin, F. (1995): A comparative study on heavy metals $(\mathrm{Cu}, \mathrm{Cr}, \mathrm{Pb}$ and $\mathrm{Ni}$ ) accumulates in the tissue of Carp. Cyprinus carpio and Nile fish. Tilapia niloticus Tr. J. of Zoology 19: 165-171.

Cavalli, L., Cassani, G., Pravettoni, S., Nucci, O., Larrizarin, M., Zatta, A. and Vigano, L. (2000). Surfactants in Sediments. CLER Review.6 (1):32-43.

Chang, S.V. Zdanowicz \& R.A. Murchelano. (1998). Associations between liver lesions in winter flonder (Pleuronecte Americans) and sediment chemical contaminants from north-east United States estuaries. J Marine Sci. 55:954-969.

Cox, C. (1998); Glyphosate (roundup). J. Pestic. Reform. 18: 3-17.

Department of Petroleum Resources (DPR)., (2002): Environmental Guidelines and Standards for the Petroleum Industries in Nigeria. (EGASPIN) Revised Edition.

Donaldson, E. M. and Dye, H. M. (1975): Corticosteroid concentrations in Sockeye salmon. Onchorhnchus nerka exposed to low concentrations of copper. J. Fish.Res. Board Can. 32:533-539.

Eligaard, E. G. and Guillort, J. L. (1988): Kinetic analysis of the swimming behavior of Bluegill sunfish, Lepomis macrochirus Rafinesque, exposed to copper: hyperactivity induced by sublethal concentrations. J. Fish. Biol 33:601-608

Eniola, K.I.T. and Olayemi, A.B. (2002). Some Aspects of Bacterial-Detergents interaction in fresh water environment. Bioscience Research communication 14 (6): 645-649.

Farkas, A., Salanki, J. and Specziar, A. (2002): Relation between growth and the heavy metals concentrations in organs of bream, Abramis brama $L$. populating lake Blaton. Arch. of Environ. Contam. Toxicol. 43(2): 236243.

Fryer, J. D. (1977): Weed control handbook Vol. 1, Edited by Make Peace, pp. 384-389.

FEPA, (1991). Federal Environmental Protection Agency. S.1.8 National environmental protection agency [Effluent discharge Limitation]

Frieberg, L., Piscator, M. and Northberg, G. (1971): Cadmium in the environment. Chemical Rubber, Cleveland.
Gledhill, W. E. (1974). Linear Alkybenzene Sulfonates: Biodegrdation and Aquatic interactions Adv. Appl. Microbiol. 17:265-293.

Haaparanta, A., E.T. Valtonen, R. Hoffaman \& J. Colmes. (1996). Do macrophages centres in freshwater fishes reflect the differences in water quality? Aquatic Toxicology, 34:253-272.

Hinto, D.E., Baumann, P. C., Gardner, G. R., Hawkins, W. E., Hendricks, J. D., Murchelano, R. A. and Okihiro, M. S. (1992): Histopathologi biomarkers. In: Huggett, R. J. Kimerle, R. A., Mehle, J. R. Bergman, H. L., Editors, Biomarkers: Biochemical, Physiological and Histological Markers of Anthropogenic Sress, Lewis Publioshers, Boca Raton (1992), pp. 155-209.

Huang, X., Ellis, T. G. and Kaiser, S. K. (2000). Extant Biodegradation Testing with Linear Alkbenzene Sulfonate in Laboratory and Field activated sludge Systems. WEFTEC 2000. Water environment federation.

Ikpi G.U., Ogunyemi O.O., Offem B. (2003): Toxicity of industrial effluent on Oreochroomis niloticus fingerlings in Ado-Ekiti, Nigeria 1(1) 177 - 182

Kulakkattolickal, A. T.and Kramer, D. I. (1997): The role of Air Breathings in the Resistance of Bimodally Respiring Fish to water. J. Fish. Biol. 32: 119-127.

Kelly, W. R. (1979): Veterinary Clinical Diagnosis $2^{\text {nd }}$ ed. Balliere Tindall, London pp. 266-279.

Kock, G., Triendi, M. and Hofer, R. (1996): seasonal pattern of metal accumulation in Arctic char (Salvelinus alpinus) from an oligitriphic Alpine lake related to temperature. Can. J.Fish. Aquat. Sci. 53:780-786.

Luna, L. G. (1968). Manual of Histologic Staining methods of the Armed forces institute of pathology. Migraw Hillbuk co; New York.

Lightowlers, P. (2004): Still dirty: A review of action against toxic products in Europe. A report for WWF-UK.

Malik, R, ans Hodgson, H. (2002): The relationship between the thyroid gland and the liver. Quart. J. Med. 95: 559-569.

Mcavoy, D. C., Eckhoff, W. S. and Rapaport, R. A. (1997): The fate of Lineart alkylbenzene sulfonates in the environment. The Clear Review 3(1):4-7.

Myers, M. S., Johnson, L. L., Olson, O. P., Sther, C. M., Homess, B. H., Collier, T. K. and McCain, B. B. (1998): Toxicopathic hepatic lesions as biomarker of chemical contaminants exposure and effects in marine bottomfish species from the northesther and Pacific Coast. U. S. A. Mar. Pollut. Bull. 37: 92-113.

Odiete, W.O. (1999): Impacts associated with water pollution. In: Environmental Physiology of Animals and Pollution. 1st Edition. Diversified Resources Ltd., Lagos, Nigeria, pp. 187 - 219. and 261. 
Ogundiran, M. A.,Fawole, O. O. and Adewoye, S. O.(2007). Effects of Soap and Detergent Effluents on the Haematological Profiles of Clarias gariepinus. Science focus 12(1) 84-88.

Ogundiran M.A, Fawole, O.O., Adewoye, S.O. and Ayandiran, T. A. (2009) Pathologic Lesions in the Gills Structures of Clarias gariepinus on exposure to sub lethal concentrations of soap and detergent effluents. $\mathrm{J}$ Cell and Animal Biol 3 (5), 078-082

Okpokwasili GO, Nwabuzor CN (1988). Primary biodegradation of anionic surfactants in laundry detergents. Chemosphere 17: 2175-2182.

Okwuosa V.A and Omoregie E. (1995): Acute toxicity of Alikylbenzene sulphonate. Aquaculture Res. 26: 755 758pp.

Olojo, E. A. A., Olurin, K. B., Mbaka, G. and Oluwemimo, A. D. (2005). Histopathology of gills and liver tissues of the African catfish Clarias gariepinus exposed to lead. Afr. J. of Biotech. 4 (1), pp. 117-122.

Omoniyi, I., Agbon, A. and Sodunk, S.A. (2002): Effects of lethal and sub-lethal concentrations of tobacco (Nicotiana tobaccum), leaf dustextracutum on weight and haematological changes in Clarias gariepinus (buchell, 1822). J. Appl. Environ. Man. 6: 37-41.

Omoregie, E, Ufodike, E.B.C and Keke, I.R. (1990): Tissues chemistry of $O$. niloticus exposed to sublethal concentrations of Gammalin 20 and Actellic 25EC. J. of Aquatic Sci, 5: $33-36$

Oyelese, O. A. and Faturoti, E. O. (1995): Growth and mentality estimates in Clarias gariepinus fed graded levels of processed cassava peels J. Trop. Forest Res. 11: 71-81.

Pacheco, M. and Santos, M.A. (2002). Biotransformation, genotoxic and histopathological effect of environmental contaminants in European eel (Anguilla anguilla).Ecotoxicological and Environmental Safety, 53: 331-347.

Painter, H. A. and Zebel, T. (1989): The behavior of LAS in sewage treatment. Tenside sulfonates detergent. 26: 108-115.

Paris-Palacios, S., Biagianti-Risboug, S. and Vemet, G. (2000). Biochemical and (ultral) structural hepatic perturbations of Brachyodanio rerio (Teleostei, Cyprinidae) exposed to two sub lethal concentrations of copper sulfate. Aquatic Toxicol, 50: 109-124.

Rahman, M. Z., Hossain, Z., Mullah, M. F. R. and Ahmed, G. U. (2002): Effects of diazinon 60EC on Anabus testudineus, Channa punctatus and Barbades gomonotus. NAGA. The ICLARMS Quarterly, 25: 811.

Reish, D.J and Oshida, O.S (1987): Manual of methods in aquatic environment research. Part 10, short term static bioassay. FAO Fish Tech. Pap. 47-52pp.

Rocha, E and Monteiro, R. A. F. (1999): Histology and Cytology of fish liver: A review, p. 321-344, In: Saksena D. N. (ed.) Ichthyology: Resent research advances. Science Publishers, Enfield, New Hampshire.

Ruiswell, R.E., Brimblecombe, P., Deut, D. L. and Liss, P. S. (1992). Environmental Chemistry, the Earth-Airwater Factory. Edward Arnold. Great Britain.

Schalm, O. W., Jain, N. C. and Carrol E. J. (1975): veterinary haematology, $3^{\text {rd }}$ Ed., Philadelphia, Leaard Febiger, pp. 15-18.

Solbe, J. F. (1995): Fresh water in: Handbook of Ecotoxicology (Edited by Peter Collins) Black Well Science Ltd. Osneymeed OX 20EL. pp 683

Srivastava A. K. and Srivastava, A. K. (1994): Review of investigations on biological effects of Selenium on fish. J. Freshwat. Biol. 6 (4): 285-293.

Swisher RD (1975). Surfactants: from recalcitrant to docile. In: Proc. International iodegradation Symposium (Eds.) Sharpely JM, Kaplan AM, pp. 853-865.

Van Dyk, G.M. Pieterse, J.H.J. and Vuren, M. (2005) Histological changes in the liver of Oreochromis mossambicus (Cichlidae) after exposure to Cadmium and zinc. A review of Ecotoxicology and Environmental Safety 2 (1) 1-9.

Warren, C. E. (1977): Biology and water pollution. W. B. Sanders and Company Philadelphia, USA, 434pp.

WHO (1988): International standards for drinking water 3rd Edition. World Health Organization, Geneva.

WHO - World Health Organization (1996). International programme on chemical safety environment health criterial 169 Linear Alkylbenzene Solfonates and related compounds. World Health Organization Geneva. 